\title{
"Writing a Name in the Sky": Rancière, Cavell, and the Possibility of Egalitarian Inscription
} ALETTA J. NORVAL University of Essex

\begin{abstract}
$D$ emocratic theory is often portrayed as torn between two moments: that of disruption of rule, and the ordinary, ongoing institutionalization of politics. This dualism also marks contemporary democratic theory. In Jacques Rancière's theory of politics it takes the form of an emphasis on the ruptural qualities of the staging of novel democratic demands and the reconfiguration of the space of political argument. The reconfiguration of existing political imaginaries depends upon a moment of inscription, which remains underdeveloped in Rancière's work. Arguing that the possibility of inscription is indeed thematized in Rancière's more historical writings, but is often ignored by commentators, this article seeks to draw out the implications of a focus on inscription for democratic theory and practice. To flesh out this account, the article draws on Cavell's writings on exemplarity and the role of exemplars in fostering both critical reflection and the imagination of alternatives. The focus on such exemplars and an aversive, nonconformist ethos together facilitate a better understanding of what is required for such novel demands to be acknowledged and inscribed into democratic life.
\end{abstract}

$\mathbf{C}$ ommenting on recent events in Egypt, Ahmed Badawi described in his blog how one year ago, "street children flocked to Tahrir and other major squares in Egypt and threw their lot in with the revolutionaries." He argues that they felt, perhaps for the first time in their lives, "a sense of comradeship" with the more affluent youth and "found vehicles to vent their anger at a society that had routinely ignored them and, particularly, a police force that had abused them and treated them as animals and criminals." Through staging their protests on Tahrir Square, they became part of the "common cause uniting all Egyptians." Political life today is replete with eruptions of popular protests, which seek to make visible a range of injustices, both familiar and unfamiliar. Whether it is the "Arab Spring" or more local struggles for equality-one need only think here of the ongoing contestation of the demands for same-sex marriages ${ }^{2}-$ such struggles foreground deeply felt senses of wrong, thrusting them into visibility. In originary moments

Aletta J. Norval is Professor of Political Theory, Department of Government, University of Essex, Wivenhoe Park, Colchester CO4 3SQ, United Kingdom (alett@essex.ac.uk).

I have incurred many intellectual debts in writing this article. I presented earlier versions of it in the Humanities Centre, Johns Hopkins University, as well as at the Chicago Political Theory Workshop. I thank my hosts, Jane Bennett and William Connolly at Johns Hopkins and Robert Gooding-Williams at Chicago, as well as the participants in those seminars for probing discussion and valuable suggestions. They have helped in developing the final arguments I present here. I also owe a debt of gratitude to others who gave generously of their time in commenting on various versions of this article: David Howarth, David Owen, Davide Panagia, Thomas Dumm, and Hugh Ward. I am grateful to the anonymous APSR referees for comments and criticisms that guided me in my final revisions. My deepest gratitude goes to Coeditor Kirstie McClure for her substantive comments and consistent support throughout the publication process.

${ }^{1} \mathrm{http} / / /$ www.transform-egypt.blogspot.com/ (accessed January 30, 2012).

2 On 3 December 1996, Hawaii became the first U.S. state to recognize same-sex marriage. Since then same-sex marriage has been introduced in six U.S. states, in addition to countries such as Spain, Portugal, South Africa, and the Netherlands, where it is already incorporated on the statute books. such as these, new identities and ways of life that were once invisible and excluded may be "ushered onto the threshold of justice" (Honig 2009, 47). But, as Honig argues, and as we know from experience, there are no guarantees here. These events bring home to us in a particularly forceful manner the difficulty, as well as the high costs, associated with "getting things onto the political agenda."

Such struggles articulate specific claims and demands, while they also invoke alternatives to the existing order. In doing so, they seek to project and inscribe new and unheard-of ways of being and acting, beyond the currently acceptable political languages and norms of our times, onto the political agenda. In this article, I explore this idea of "writing a name in the sky" by engaging with two theorists-Jacques Rancière and Stanley Cavell-who both address issues relating to the processes through which challenges to existing political languages and imaginaries are enacted. ${ }^{3}$ These theorists each offer distinctive insights into different aspects of these processes. I focus in particular on one key aspect, namely that of the transition from the initial articulation of democratic demands to their inscription onto a horizon that would allow for their flourishing and extension to other areas of social and political life. ${ }^{4}$ This movement captures an important set of issues facing our societies today, while also reflecting wider debates

\footnotetext{
3 The concept "imaginary" designates a space of representation, which has the function of representing the unity of society in modernity, in the absence of a God-given order (Lefort 1986). Laclau (1990) suggests that a collective political imaginary acts as a horizon on which a multiplicity of demands can be inscribed. Horizons make possible and limit what may appear as relevant subjects and objects of politics. Examples of political imaginaries include, for instance, "the free market," "the welfare state," and "Kemalism."

4 The notion of inscription is drawn from Derrida's reading of speech act theory, and it denotes the idea that meaning is constituted, partly, by reference to the specific context in which it is "inscribed" (Derrida 1988). Here I deploy the term in a similar sense in order to indicate both the fact that the meaning of any political demand is shaped by the context in which it is inscribed and the fact that novel demands require inscription into wider political imaginaries if they are to become effectively institutionalized.
} 
in political theory about the dualism between founding moments and processes of institutionalization. ${ }^{5}$ Contemporary societies in transition to democracy, as well as societies in the process of deepening democratic political participation, are faced with the challenge of responding to and harnessing democratic energy, insight, and imagination without, however, immediately subordinating this vitality to the potentially deadening weight of procedures, rules, and institutions. Given these concerns, we need to give attention to precisely how extant systems are affected by the articulation of novel and often challenging demands; what processes contribute to and enable the inscription of demands onto the wider political agenda so that the existing political order is altered as a result; and what sort of political ethos is needed to enable such processes to develop in a democratic direction. I turn to the writings of Rancière and Cavell to think through what is required practically as well as theoretically if we are to respond imaginatively to democratic demands and if we are to learn from and harness the critical insights arising from such demands in the service of deepening democracy.

Two scenarios may be used to frame the issues I seek to address here. These will be familiar to readers of Rancière and Cavell, and they resonate with contemporary political events and struggles. The first relates an ancient event, as told and retold by Livy and a host of others, of the secession of the Roman plebeians on the Aventine Hill. The second is a commentary on Nora's position in Ibsen's A Doll's House. On the face of it, these scenarios are very different. Yet, I shall argue, they share an important set of concerns arising in democratic theory today. By juxtaposing and bringing these scenarios and thinkers into conversation with one another, we can enrich our understanding of contemporary debates concerning the relation between the expression of new demands and their articulation into the political life of a community, and of the role of a democratic ethos and political imagination in these processes.

\section{SCENARIO 1}

In Disagreement Rancière (1999) draws on PierreSimon Ballanche's writings recounting the tale told by Livy of the secession of the Roman plebeians on the Aventine Hill. The plebeians seceded-literally withdrew from the city-as a result of the harsh rule of Appius Claudius (Parmele 2006, 44). In response, the patricians conceded some of their demands and created the offices of the plebeian tribunes. For Rancière, the significance of this retelling of the tale is that Ballanche notes Livy's inability "to think of the event as anything other than a revolt, an uprising caused by poverty and anger and sparking a power play devoid of all meaning" $(1999,23)$. Livy fails to be able to supply the meaning of the conflict because he does not put it in the right context, that of "a quarrel over the issue of speech itself."

\footnotetext{
${ }^{5}$ For a recent treatment of this issue in the work of Weber, Schmitt, and Arendt, see Kalyvas (2008).
}

Rancière (1999, 23) suggests that Ballanche effectively restages the conflict as one in which the "entire issue at stake involves finding out whether there exists a common stage where plebeians and patricians can debate anything." In Ballanche's view, the relation between plebeians and patricians is structured through patrician domination, which holds that those beings deprived of logos-the plebeians-are not capable of speech; they are beings of no ac/count, capable only of noise, of a sort of "lowing." Not unlike those participating in the Arab Spring, the plebeians faced with this situation establish another order-another division of the sensible-by setting themselves up as speaking beings, "sharing the same properties as those who deny them" the ability to speak (Rancière 1999, 24). They do so by engaging in a number of speech acts "that mimic those of the patricians." Ballanche's rendering of this tale makes visible that what is going on is the "staging of a nonexistent right" (Rancière 1999, 25).

When the Senate's emissary, Menenius, delivers his apologia to the plebs, stating the necessary inequality between the patricians and the plebeians, the plebs are already equals, for they can understand it and, indeed, after listening politely, respond in kind by asking for a treaty. ${ }^{7}$ As a result, the Roman Senate concludes that "since the plebs have become creatures of speech, there is nothing left to do but to talk to them" (1999, 26). Hence, they are successful in making the transition from interruption to inscription. I shall argue, however, that Rancière's analysis here moves far too quickly. He fails to explore the Roman Senate's response to the plebeians. Accounting for the role of responsiveness in bringing about change to the extant order is crucial, and stands at the heart of Cavell's work, and of his reading of $A$ Doll's House.

\section{SCENARIO 2}

The second scenario is taken from Cavell's discussion of Ibsen's A Doll's House and seeks to capture the difficulty of expressing senses of injustice that do not fit the parameters of current moral and political discourse

\footnotetext{
${ }^{6}$ Rancière suggests that politics concerns a distinction between those who have speech (logos) and those who do not. Possession of speech as logos is exclusive to human beings and allows distinctions to be made between what is just and what is unjust. Having speech signifies enrolment in the city (Rancière 1999, 23). Those who lack speech are capable only of "noise" (phônê). As he puts it, "the difference is marked precisely in the logos that separates the discursive articulation of a grievance from the phonic articulation of a groan" (1999, 2).

${ }^{7}$ Menenius Agrippa delivers his apologia in the form of the fable of the Belly and its Members (Patterson 1991, 4). The fable recounts the attempt made by the members of the body (the hands, eyes, ears, feet, and tongue) to conspire against the belly, which they thought devoured the fruits of their labour. Patterson notes that the fable articulates in symbolic terms "some of the most intransigent problems in political philosophy and practice" relating to the relation between ruler and ruled, with "the image of the human body and its nutritional needs as a symbol of the distribution of wealth in the body politic." This fable, she argues, has historically been open to diverging appropriations, not only those reinforcing hierarchy, but also those making the case of the rebellious members (Patterson 1991, 111-37).
} 
(Cavell 1990). ${ }^{8}$ Cavell's reading is aimed at those people within existing democracies, who take themselves to be "above reproach" in response to the resentment expressed by members of society who feel aggrieved. ${ }^{9}$ Hence, in contrast to that offered by Rancière, Cavell's focus is on those who are in dominant positions, and more particularly on the question of their responsiveness to, as well as acknowledgment of, the expression of senses of wrong by others. In the play, Nora struggles to express her sense of injustice to Torvald, her husband of eight years. When challenged by him as to why she secretly borrowed money and then skimped on household expenses to repay interest, she emphasizes the fact that although she knows that most people would agree with him, and that he has "warrant for it in books," she cannot "be satisfied any longer with what most people say, and with what's in books." She must have the opportunity to think things out for herself, an opportunity she has thus far been denied. In this, Cavell $(1990,110)$ suggests, Nora feels herself representative "beyond her personal resentment," thus drawing attention to thousands of women like her. Torvald, in turn, questions her moral sense, and accuses her of "talking like a child," like one who does not understand the world she lives in, thus depriving her, again, of a voice (Cavell 1990, 109). When, at the climax of the story, Torvald tells Nora that he forgives her-instead of begging her forgiveness-Nora leaves him. In so doing she enacts change; she can no longer live in an order that denies her a voice, her voice and more, the voice of thousands like her. Through the example of Nora, Cavell captures the experience of a sense of injustice that is inexpressible in the terms of prevailing discourse, but where, as he puts it, misery is clearly unmistakable $(1990,112)$. And the question arises: What does one make of such an experience in a context governed by a democratic grammar? What role does responsiveness, or the lack of it represented by Torvald, play here?

What is at stake for Rancière and Cavell in each of these cases is the possibility of speaking and of being heard, even though they deal in different fashions with the processes and consequences of the acts through which something that was previously excluded is made visible. Rancière tends to refrain from explicitly engaging with the issues that arise after moments of rupture, when previously excluded senses of wrong become visible and alternative ways of doing things need to become institutionalized, and thus inscribed into the current order. This refusal arises from his much remarked upon division between "politics" and

\footnotetext{
${ }^{8}$ As Cavell (1990, xxxviii) puts it, "What if there is a cry of justice that expresses a sense not of having lost out in an unequal yet fair struggle, but of having from the start been left out."

${ }^{9}$ This argument is developed contra Rawls who, Cavell suggests, "in effect claims that my sense of living in a society which in my judgement exhibits a favourable degree of partial compliance is one which, in response to an expression of resentment levelled by an aggrieved member (permanent or impermanent, I believe) of that society, I can say my conduct is above reproach (422). (What 'in effect' means here is critical. Rawls does not explicitly claim what I find him implicitly to claim here;" Cavell 2004, 171).
}

the "police order,"10 as well as the ruptural picture of democracy that accompanies this distinction. Cavell, on the other hand, focuses overtly on questions of responsiveness, a focus that is crucial if one is to elucidate fully, not only the transition from disruption to inscription, but also the character of practices of inscription. What stance, for instance, would facilitate a democratic form of inscription, rather than a mere incorporation of demands? ${ }^{11}$ What role does a democratic ethos play here? Despite the differences between these thinkers, I shall suggest that what they share is sufficient to draw them together into a conversation that is potentially mutually enriching. My key claim then is that Rancière does not do enough by way of addressing questions regarding the processes through which democratic challenges find a foothold in existing orders. Given this, a turn to Cavell may be fruitful, for he offers a picture of democratic responsiveness that thematizes precisely those processes. Without addressing the interconnections between the interruption of an existing order by novel demands and their inscription into and change to that order, I shall argue, any account of democratic rupture remains fundamentally flawed.

In both of these scenarios, there are subjects who are to a greater or lesser extent excluded from the extant order, with the result that their claims cannot be heard as claims (at least not yet). ${ }^{12}$ Yet their actions, Ballanche suggests, consist of "writing a name in the sky" in that they open up new ways of being and acting. How does "writing a name in the sky" facilitate carving out a place in the community of speaking beings, which does not

\footnotetext{
${ }^{10}$ Rancière's use of the term "police" should be understood in relation to two sets of doctrine-the "reason of state" and the "theory of the police"-arising with the formation of modern European nation states (Foucault 1988; Habermas 1992, 30). Foucault $(1988,74)$ notes that the former refers to attempts to "define how the principles and methods of state government differed ... from the way God governed the world, the father his family or a superior his community," whereas the latter refers to "a governmental technology peculiar to the state." Hence, here "police" is not understood as an institution functioning within the state. Rather, it concerns the observation and regulation of all dimensions of life, amongst them morals, health, public safety, labor, and population. Thus, "the police" covers "the whole new field in which centralized and administrative power can intervene" (Foucault 1988, 80). It was encapsulated in the emergence of Polizeiwissenschaft-which incorporated the public law, administration, public health, urban planning-in the first half of the eighteenth century in Germany. For a historical overview of the emergence of the reason of state, see Viroli (1992); for a discussion of the emergence of the theory of the police, see Foucault (2007).

11 The relevant contrast here is between the cooptation of demands (mere incorporation) and an ethos that takes seriously the idea that new demands, if taken on board, require a reworking of the extant order. Rancière's worry is that the extant order will always be able to incorporate new demands. Cavell's writing addresses this issue through the emphasis on responsiveness. Hence, I shall argue, a democratic form of responsiveness is one that works through the consequences for an extant order of new demands, and places a premium on the responsibility to respond, rather than turn away, simply justify the existing ordering of affairs, or attempt to render powerless and make ineffective, new demands.

12 This covers many facets of the issue that are not discussed here, including the question of what is required in terms of knowledge, leadership, and processes of formation of collective identities. Here I am concerned less with these general processes than with what is required in a democratic order to enable it to engage with and
} respond to such demands. 
yet exist? In this process of carving out a new space in which something or someone may appear, what is the relationship between speech and that which exceeds speech, insofar as it involves an emphasis on seeing and on staging? What view of subjectivity and of political community does this presuppose?

In seeking to address these questions, I shall suggest that Rancière's characterization of democracy is caught on the horns of a familiar dilemma, which needs to be resolved if convincing answers to these questions are to be provided. In a nutshell, the problem is this. On one hand, democracy is presented as ruptural, as a moment of break from the prevailing order. On the other hand, the democratic experience must be able to intervene in and reconfigure that order, which is possible only if it does not take the form of a rupture or a complete break. This much is made clear by the plebeian case. I shall argue that the resolution of this dilemma lies not in a choice between the two horns, but more in what, in Wittgensteinian fashion, one may call an attempt to dissolve the problem through a careful reconsideration of Rancière's conceptions of political subjectivity, political community, and, with them, his conceptualization of the possibilities and mechanisms of political change. My discussion of these conceptions allows me to attend to the reasons for Rancière's refusal to flesh out these mechanisms. Making these reasons visible is not, however, sufficient. Further reflection is needed on their place in Rancière's writings. In contrast to familiar interpretations of Rancière that present him as a theorist of rupture who is able only to "momentarily expose the injustice at the heart of rule" (Markell 2006, 3), this article makes the case that there are neglected resources in Rancière's writings that offer some means of addressing the practices of inscription, which would allow expressions of wrong and novel demands to reshape the existing political order. Arguing that the ruptural version rests too heavily on a reading of only a limited number of his more explicitly theoretical writings, this article suggests that his historical writings offer rich resources for understanding how these practices operate. Drawing out these insights and reflecting on the work that historical examples do in his writings, it reorients discussion to focus on the role of exemplars in bridging the gap between interruption and inscription. Here historical examples play an important role in making available alternatives with which one can identify and which could act as "catalysts of conversion," as Tocqueville put it (Frank 2011, 386). To flesh out these insights further, I turn to Cavell, whose perfectionist rendering of exemplarity, with its link to an aversive ethos, ${ }^{13}$ furnishes us with a way to address some of the remaining shortcomings of Rancière's account. The

\footnotetext{
13 The term "aversive ethos" is drawn from Cavell's reading of Emerson (Cavell 1990,33-63). It emphasizes the role of oppositional thinking in developing a critique of the present state of things, which calls for a transformation of that order and of the self. An aversive ethos is thus closely linked to perfectionism for Cavell, because becoming "averse" to conformity means we need to transform ourselves, aspiring to a better state of self and of society. For an analysis of the South African Truth and Reconciliation Commission as an exemplar of an aversive ethos, see Norval (2007).
}

turn to ethos is controversial from a Rancièrian point of view. Nevertheless, the way it is elaborated in Cavell's writings not only addresses the concerns that he expresses, but also makes available additional resources to extend and deepen the reach of Rancière's insights into ongoing democratic practices of contestation.

Rather than treating these two theorists as engaged in fundamentally divergent enterprises, this article suggests that they could both be argued to contribute to thought that seeks to bridge the division between rupture and inscription that is characteristic of so much democratic theory. Democratic theory is torn between two moments: that of the extraordinary, the moment of founding and of constituent power, and that of the ordinary, the institutional and constituted power. The extraordinary/ordinary couple echoes other forms in which this dichotomy-between revolutionary founding acts and institutional politics-has appeared both in theorizing democracy and in thinking about the nature and character of politics more generally (Laclau 2005; Markell 2006). I think here of the work of constitutional scholars such as Ackerman (1991), who emphasizes the need for popular participation in moments of constitutional innovation, as well as of attempts to reflect upon the conundrums posed by demands for transitional justice and the refounding of states, not ex nihilo, but in the aftermath of sometimes protracted conflicts. In each of these cases, different aspects of the problem of instituting and maintaining a democratic order are emphasized.

The significance of the interpretation proposed here is that it suggests that instead of concentrating on the horns of the dilemma, a different way of approaching the matter is needed. Rather than remaining fixated on either side of the dichotomy, we need to look at the processes and mechanisms that are available to us for bridging the division. Such a shift may allow us to see the problem in a different way, thus disclosing aspects of it that may allow us to dissolve it. ${ }^{14}$ The figure of "writing a name in the sky"-projecting and inscribing new and unheard-of ways of being and acting onto existing political imaginaries-captures and condenses what is at stake here. It shifts our gaze onto the mechanisms through which senses of wrong are inscribed into existing political languages such that they are reconfigured as a result, and to the conditions for doing so. The writings of Rancière and Cavell, when read together, offer a nuanced and novel way of thinking about such mechanisms and practices. Hence, Kalyvas $(2008,4)$ is correct to suggest that we need to rework the dualism between the extraordinary and the ordinary, and appropriate the extraordinary in order to expand the scope of democratic experience, retaining the energies, freedom, and imagination that are associated with acts of founding. What this reading of Rancière and Cavell offers is a vision of how this may be done.

\footnotetext{
$\overline{14}$ In this, I follow a Wittgensteinian strategy of reading. Wittgenstein argues that in approaching the problems of philosophy, rather than solving them, we need to dissolve them. I take this to mean that we need to approach problems in such a manner that new aspects become visible, and older ones dissolve.
} 


\section{DEMOCRACY, VISIBILITY, AND THE STAGING OF WRONGS}

Rancière's view of "democratic life" seeks to distance itself from what is problematic, if not downright objectionable, in discourses on democracy, both historical and contemporary (2006). These include discourses expressing hatred of democracy, as well as various forms of critique that acknowledge democracy but seek to confine it within certain limits (Rancière 2006, 2). ${ }^{15}$ Contemporary expressions of hatred against democracy, he argues, do not call for more "real" democracy; nor do they complain about the institutions embodying the power of the people. Rather, in these discourses the problem is located in "democratic civilization" itself: Excess is what ruins democracy and hence is what must be controlled by it. ${ }^{16}$ The image of democracy as associated with an excess that stands in need of being governed is one that goes back to Plato and it embodies what, for Rancière, is the very (improper) principle of politics itself. ${ }^{17}$ Democratic excess, he argues, is simply "the dissolving of any standard by which nature could give its law to communitarian artifice via the relations of authority that structure the social body"; it is government based on nothing other than the "absence of every title to govern." Rancière $(2006,4647)$ puts it thus:

[T]he only remaining title is the anarchic title, the title specific to those who have no more title for governing than they have for being governed. This is what of all things democracy means. Democracy is not a type of constitution, nor a form of society. The power of the people is not that of a people gathered together, of the majority, or of the working class. It is simply the power peculiar to those who have no more entitlements to govern than to submit.

In the absence of the power of birth and of wealth, what remains is the power of the people, which is the power of "anyone at all, the equality of capabilities to occupy the position of governors and of the governed." Hence, democracy is marked by the fact that it rests on the absence of a foundation.

Rancière fleshes out his understanding of this absence of foundation that characterizes the beginning of

\footnotetext{
$\overline{15}$ Rancière notes that hatred of democracy is as old as democracy itself. In Ancient Greece the term was one of insult, signifying the government of the multitude that would ruin any legitimate order (Rancière 2006,2). In our contemporary world, hatred of democracy is often expressed by spokespersons living in democracies. Rancière (2006, 7-8) lists a number of recent writings on democracy, including the Trilateral Commission Report-The Crisis of Democracy-as exemplifying the paradox of democracy: "as a social and political form of life, democracy is the reign of excess. This excess signifies the ruin of democratic government and must therefore be repressed by it."

16 Rancière $(2006,7-8)$ notes that the historical remedy for this sort of excess consisted in redirecting "feverish energy activated on the public stage towards other ends" often, as is today also the case, toward the search for material prosperity.

${ }^{17}$ It should be noted that Rancière's "return to the classics" is not one that seeks to affirm the Aristotelian idea that politics is based on a natural disposition to political life. Rather, it is a return that seeks to show that democracy, already in the classical texts, marks the place of those who have no specific properties allowing them to govern.
}

politics in terms of a division of the sensible. ${ }^{18}$ The institution of democracy takes place with the creation of a space "made of disconnected places" (Rancière 2006, 46-47), a new topography that redistributes places and reconfigures what is visible and invisible, what can be seen and heard and what cannot be seen and heard. Politics, in this view, is a matter of aesthetics first and foremost, in the sense in that it concerns the division between the perceptible and the imperceptible. The logic of the police-the extant order-distributes bodies within the space of visibility; it is challenged by political acts that shift bodies from the places assigned to them, thus making visible "what had no business being seen." Political activity here takes a particular form. It is concerned with "conflict over the existence of a common stage and over the existence and status of those present on it. It must first be established that the stage exists for the use of an interlocutor who can't see it and who can't see if for good reason because it doesn't exist" (1999, 26-27). The plebs on the Aventine Hill and the Tahrir protesters must first establish their right to be counted as parties to the dispute, and they do so through the declaration of a wrong. Rancière $(1999,27)$ thus argues that

Parties do not exist prior to the conflict they name and in which they are counted as parties.... Politics exists because those who have no right to be counted as speaking beings make themselves of some account, setting up a community by the fact of placing in common a wrong that is nothing more than this very confrontation.

On this reading democracy does not concern itself with questions of institutional design or a particular "human disposition" that would characterize it. It excludes activities of representation, as well as any concern with regimes or forms of government. ${ }^{19}$ In contrast, democracy concerns

the system of forms of subjectification through which any order of distribution of bodies into functions corresponding to their "nature" and places corresponding to their functions is undermined, thrown back on its contingency. (Rancière 1999, 101, emphasis added)

This partition takes place through the articulation of a wrong. ${ }^{20}$ A wrong is a "mode of subjectification in

\footnotetext{
${ }^{18}$ Rancière (2009a, 277) suggests that the "distribution of the sensible" establishes a link between "being in a specific space and time, performing specific activities, and being endowed with capacities of seeing, saying, and doing that 'fit' those activities."

${ }^{19}$ Rancière suggests that we should not think of representation as a mechanism or system invented to compensate for the growth of populations, nor as a form of adaptation of democracy to vast spaces and modern times. Like Tully, Rancière $(2006,53)$ notes that the assimilation of democracy to representative government is a recent phenomenon, and one that has been used by elites to exercise power de facto. The term democracy, Tully (2008a, 155-56) argues, came to be associated with "representative democracy" only in the late eighteenth century."

${ }^{20}$ I use the term articulation here in its theoretical sense, as developed by Laclau and Mouffe $(1985,113)$. In contrast to mediation, it is a process that binds together elements or objects that have no natural or necessary belonging together.
} 
which the assertion of equality takes its political shape" (Rancière 1999, 39). The protestors in Tahrir Square and the plebs on the Aventine Hill stage such a wrong by conducting themselves like beings with names, as equals to those who have previously dominated them. ${ }^{21}$ The staging of a wrong and the verification of equality take effect through attempts to refashion and challenge the existing division of the sensible. They occur rarely $(1999,17)$ and do not "express" pregiven, objective interests. "Speaking out," Rancière suggests, is not "awareness and expression of a self asserting what belongs to it" $(1999,37)$. Rather, it is a process of disidentification, removal from a "natural" place (1999, 36).

It is also through this process that political bonds are created. Political bonds, Rancière suggests, are not created by identification with a victim or his or her cause, but as a result of disidentification from the dominant terms or available subject positions. As a result, political community is not based upon having something positive in common, but rather is a sharing of "what is not given as being in-common," ties that "bind the given to what is not given" $(1999,138-39)$. On this reading, democracy as a political mode of subjectification has three distinguishing characteristics. First, it is a kind of community that is defined by the appearance of the people, such that it reconfigures the regime of the visible. Second, this space is occupied by a people of a particular kind: It is a unity that superimposes the effectiveness of a part of those that have no part, "floating subjects that deregulate all representation of places and portions" (1999, 99-100). Third, the place where the people appear is a place where a dispute is conducted. Hence its ruptural quality. ${ }^{22}$

\section{RANCIÈRE: A THEORIST OF RUPTURE?}

Despite the crucial insights Rancière offers, there are serious questions to be raised about this characterization of democracy. Numerous critics have voiced their concern over what variously has been called Rancière's "non-political" understanding of politics (Dillon 2003), the too sharp division posed between politics and the police order, and his emphasis on the

\footnotetext{
${ }^{21}$ His understanding of equality and its verification is of crucial importance because it distinguishes a political from a nonpolitical wrong (Rancière 1999, 39).

22 As Rancière $(1995,49)$ puts it, "Democracy is the community of sharing, in both senses of the term: a membership in a single world which can only be expressed in adversarial terms, and a coming together which can only occur in conflict. To postulate a world of shared meaning is always transgressive." In the sentence preceding this quotation, Rancière emphasizes the role of rupture and even of violence: "In order to uphold one's correctness other kinds of arguments have always been needed. The affirmation of the right to be correct is dependent on the violence of its inscription. Thus, the reasonable arguments of the strikers of 1833 were audible, their demonstration visible, only because the events of 1830 , recalling those of 1789 , had torn them from the nether world of inarticulate sounds and ensconced them by a contingent forced-entry in the world of meaning and visibility. The repetition of egalitarian words is a repetition of that forced-entry, which is why the space of shared meaning it opens up is not a space of consensus."
}

spontaneous and interruptive quality of democracy. As the foregoing suggests, there is indeed a deeply ingrained view of democracy as disruption. In this sense, Rancière's work echoes that of other recent theorists of democracy. Laclau, for instance, in his later writings increasingly emphasizes the disruptive quality of politics and of democracy, while denigrating concerns with institutionalization as nonpolitical, the administration of things. ${ }^{23} \mathrm{~A}$ similar position is articulated by Wolin $(2004,603)$, who contrasts the moment of experience of democracy-"a crystallized response to deeply felt grievances or needs"-to governing understood as "manning and accommodating to bureaucratized institutions" that are inherently "anti-democratic." More recently still, analogous arguments have been developed by Žižek (2011), who argues that "the name of the ultimate enemy today is not capitalism, empire, exploitation or anything of the kind, but democracy: It is the 'democratic illusion', the acceptance of democratic mechanisms as the only legitimate means of change, which prevents a genuine transformation in capitalist relations." ${ }^{24}$ Such accounts raise serious questions, not simply about the narrow conceptions that are often associated with the term "democracy," but more importantly, regarding how much we can say of and about democracy other than emphasizing its disruptive qualities. $^{25}$

Readings of Rancière that emphasize the ruptural qualities of his writings, however, often do so at the expense of ignoring the points in his writings where he distances himself from the revolutionary fervor associated with interruptive characterizations. For instance, Rancière $(1999,100)$ is critical of Lefort's portrayal of modern democracy as occupying the empty space of power precisely on this point, arguing that Lefort's work is too closely associated with "a theatre of sacrifice that originally ties the emergence of democracy to the great specters of the reembodiments staged by terrorism and the totalitarianism of a body torn asunder." ${ }^{26} \mathrm{He}$ is similarly at pains to argue that democracy is not about setting up a counterpower, a pure site where it exists in isolation from the police. This is suggestive of a more nuanced analysis of democracy that can be teased out from a discussion of Rancière's more historical work, but that needs further deepening and development.

With this in mind, let us turn to two of Rancière's key examples: the secession of the plebs on the Aventine

\footnotetext{
${ }^{23}$ Like other political theorists in this respect, Laclau's work is also marked by ambiguity. His work on hegemony suggests something quite different: not a ruptural view of politics, but one of a war of position in the Gramscian sense.

${ }^{24}$ For a nuanced reading of Žižek's rendering of democracy that situates his critique in the context of his writings, see Dean (2005).

${ }^{25}$ Markell (2006) explores a similar set of questions with regard to Arendt.

${ }^{26}$ Lefort $(1989,304)$ argues that "Power appears as an empty place and those who exercise it as mere mortals who occupy it only temporarily or who could install themselves in it only by force or cunning." Rancière (2003, para. 13) also further suggests, contra Lefort, that it is not productive to think of politics in terms of a structural void.
} 
Hill and a revolt of Scythian slaves as recounted by Herodotus. These examples share an emphasis on staging in struggles to verify equality. ${ }^{27}$ Only the former, however, demonstrates a movement that goes beyond mere interruption. In the case of the Scythian slaves, what initially appears to be a successful demonstration of equality turns out to be of limited effect (Rancière 1999, 12-13). After nearly three decades away battling the Medes, a Scythian army returned home, only to be confronted by a generation of sons, sprung from their own wives and fathered by their slaves. Determined to oppose the army, the slaves started to act as if they were the equals of the warriors. They built trenches and armed themselves in readiness to defend the territory. Initial attempts to reconquer the slaves by force of arms failed; but the warriors then asserted their claim to superiority bearing only horsewhips. This, Herodotus suggests, made the slaves feel that they were, indeed, slaves and not the warriors' equals (Rancière 1999, 12). What the slaves failed to do was to turn a war-generated achievement of equality into political freedom. They did not succeed in inscribing their sense of wrong onto the political horizon, in challenging the existing ordering of hierarchies.

In the case of the Aventine plebs, in contrast, a reconfiguration of the sensible does occur. A successful displacement of "natural" relations is the result of a combination of elements, consisting of the use of words, of argument, poetics, props, and the invention of names. The Aventine plebs do so by engaging in a number of speech acts, mimicking those of the patricians:

[T]hey pronounce imprecations and apotheoses; they delegate one of their number to go and consult their oracles; they give themselves representatives by rebaptizing them ... Through transgression, they find that they too ... are endowed with speech that does not simply express want, suffering or rage, but intelligence. They write, Ballanche tells us, "a name in the sky": a place in the symbolic order of the community of speaking beings. (Rancière 1999, 24 25)

Through their speech acts they bring into being new positions of speaking and acting. The plebs declare themselves to have standing with the patricians, writing a name in the sky: opening up new worlds, inventing a future that does not (yet) exist. ${ }^{28}$

\footnotetext{
${ }^{27}$ Rancière $(1999,88)$ maintains, politics is a matter of "interpreting, in the theatrical sense of the word, the gap between a place where the demos exists and a place where it does not ... Politics consist in interpreting this relationship, which means first setting it up as theatre, inventing the argument, in the double logical and dramatic sense of the term, connecting the unconnected." As several commentators have noted, "the artifice of the theatrical scene shares with politics the displacement of 'natural' relations between bodies and places" (Ross 2009, 128; see also Hallward 2006, 113).

28 The question of opening up new worlds has recently begun to receive systematic treatment (Kompridis 2006). For an insightful rendering of the opening up of new spaces of imagination in feminist politics, see Zerilli (2005), who draws on Arendt to develop her argument. See also Frank's reading (2009) of Frederick Douglas' staging of dissensus, and Schaap's exploration (2009) of the Aboriginal tent embassy in Australia.
}

Rancière is not alone in his emphasis on the importance of the displacement of the existing division of the sensible and the need to open up new worlds. This is a familiar theme in which the writings of Heidegger and Arendt, in particular, loom large. ${ }^{29}$ Honig's $(1993,93)$ reading of Arendt focuses, for instance, on promising as an action that is unconditioned, that brings something new into being. However, she notes that the sharp division between extraordinary action and the ordinary means that this investigation of promising leaves Arendt "unable to account for how promising works." Zerilli (2005) also draws on Arendt to think through the exigencies of the emergence of the new and its inscription in feminist political imaginaries. Others suggest that the invention of the new is something we should associate with social critics and social movements whose activities could challenge and alter existing frameworks of deliberation (Bohman 1996, 140). ${ }^{30}$ Drawing on Heidegger, Spinosa, Flores, and Dreyfus (1997) also suggest that we come to see things differently as a result of activities that bring into the open and articulate experiences that "force recognition." 31 They characterize these activities as "disclosing skills." 32 All of these analyses of forms of world disclosure, of coming to see things anew, emphasize that such practices do not rely exclusively on objective measures (e.g., measuring inequality), on knowledge, and on reasongiving. Even though these may form part of the process, it is important that the emphasis on coming to view things differently is maintained. This is also the case for Rancière. As we have seen earlier, for him the possibility of engendering a new reality is not, in the first instance, an objective process. It is, rather, subjective in that it emphasizes the importance of seeing things differently. ${ }^{33}$ As he puts it with reference to his

\footnotetext{
${ }^{29}$ Kompridis $(2006,188)$, drawing on Heidegger's treatment of disclosure as a practice that facilitates a new beginning, argues that Heidegger's analysis suffers from two problems, both of which are relevant to our understanding of change and agency. First, he "failed to connect the normativity of disclosure with the normativity of intersubjectivity"; and second, he aligns disclosure too closely to truth.

${ }^{30}$ For Tully (2008b, 308), Gandhi is such an exemplar, as his "ordinary, civic and glocal life continues to move millions of people to begin to act."

31 As Spinosa, Flores, and Dreyfus $(1997,81)$ put it, "Discovering that a good friend, a trusted colleague, or a family member is gay brings about the necessary change more surely than any argument about abstract rights."

32 This includes activities such as constituting organizations that produce clarity on an issue; uncovering a disharmony as a disparity worthy of investigation; determining that the practice that the disparity reveals permeates many domains of life; cross-appropriating practices with people in other disclosive spaces so that they become sensitive to the problem and respond to it in their own domain; proposing a social change in the light of what one is seeing anew; and talking with people who are specialists in making legal changes (Spinosa, Flores, and Dreyfus 1997, 94).

33 Wittgenstein's work on aspect dawning is relevant here. The dawning of an aspect involves seeing something differently. Wittgenstein $(1989,46)$ argues with respect to the interpretation of dreams that "When a dream is interpreted we might say that it is fitted into a context in which it ceases to be puzzling. In a sense the dreamer redreams his dream in surroundings such that its aspect changes... and the result is that we say: 'Ah, now I see why it is like that, how it all comes to be arranged in that way, and what these various bits are
} 
discussion of workers in the nineteenth century, it is the framing of a new common sense that allows new forms of political subjectification to be implemented.

This process, and the world that is to come into being, has a paradoxical status. It involves a delicate negotiation of the old and the new, between the extant order and an egalitarian inscription. In his example of striking workers in nineteenth-century France, for instance, Rancière emphasizes that egalitarian inscription is dependent upon the police order and must take its resources, at least in part, from it. As Rancière (2011, 6) puts it elsewhere, politics "does not stem from a place outside of the police.... There is no place outside of the police." 34 Given this, the key question is the one with which I started, namely, how precisely does one explain the movement from interruption to inscription, and what resources does Rancière offer us in this respect? As I have suggested, in his historical writings, as well as in his writings on aesthetics and politics, there are numerous pointers. His portrayal of staging as a making visible of previously unheard-of claims and demands, of naming, and his emphasis on speech acts mimicking dominant orders present some avenues for exploration. To bring the precise contours of the issue into focus we need to recall the link between egalitarian inscription and his understanding of political subjectivity, which foregrounds processes of subjectification and disidentification, and explore whether disidentification is able to do the work he needs it to do. Is a distancing from an extant order sufficient to open up the possibility of "writing a name in the sky"? If not, what else is needed?

\section{DISIDENTIFICATION AND THE POSSIBILITY OF EGALITARIAN INSCRIPTION}

Rancière, we have seen, suggests that disidentification from the places and subject positions offered by the police is what opens up the possibility of creating political bonds and imagining alternative worlds. Here is the conundrum. New positions of identification (subjectification) have to be produced purely by negative means, through a process of disidentification. These suggestions are clearly not entirely implausible. In this respect, we might note Rancière's example of the bodies of Algerians thrown into the Seine by the French police in October 1961 during the time of the Algerian war. He argues that around those bodies "a political bond was effectively created, made up not of identification with the victims or even with their cause but of a disidentification in relation to the 'French' subject who

\footnotetext{
..' and so on." Likewise, in Rancière, the emphasis on (re)staging plays the role of reconfiguring what he calls the order of the sensible, what appears and what can appear to us.

${ }^{34}$ If, as Rancière notes, there are conflicting ways of dealing with the places that the police order allocates, if there are indeed are better and worse police orders, then we need to interrogate the conditions that would make these distinctions possible. Although Rancière $(1999,31)$ does gesture in this direction with the statement that the better one is "the one that all the breaking and entering perpetrated by egalitarian logic has most often jolted out of its 'natural' logic," he argues immediately afterward that if "the police is sweet and kind" it does not make it any less the opposite of politics.
}

massacred them." He goes on to say that such politics is the "art of warped deductions and mixed identities" constructing local and singular cases of universality. The singularity of the wrong, for Rancière, must always be distinguished from the "particularization of right attributed to collectivities according to their identity" $(1999,139)$. But one has to ask why this emphasis on disidentification and a problematization of identification? And what are the consequences of this emphasis?

The problem here arises from Rancière's association of identification with the positions of the extant order, the natural places and hierarchies offered by the police order. For instance, for him rights are not egalitarian inscriptions, but positions that are occupied by subjects within the given order, and they stand in stark contrast to the miscount of the democratic community. Although much of Rancière's $(1999,138)$ critique of discourses of right and of the political limitations of compassion and good will might well be correct, these criticisms do not suffice to address the difficulties of a negative identification or disidentification as the basis of an egalitarian inscription. Is an exclusive emphasis on disruptive identification-a politics of negation-sufficient to Rancière's account of politics? Could it provide anything other than bonds of a fleeting character? ${ }^{35}$ We have seen previously that it is plausible that under certain circumstances a rejection of an order could act as a powerful binding force. This is so particularly under conditions of severe dislocation. But whether the politics of rejection, negation, and disruption are effective in the making of alternative worlds, in the reconfiguration of the sensible, is another matter altogether.

It may be useful here to turn to another of Rancière's examples, namely the trial of the revolutionary $\mathrm{Au}-$ guste Blanqui in 1832, where there is a clearer explication of the intertwining of the old and the new, which is necessary if we are to conceptualize a reconfiguration of the sensible. Asked by a magistrate to give his profession, Blanqui responds, "proletarian." The magistrate replies that it is not a profession, to which Blanqui retorts that it is the profession of thirty million Frenchmen "who live off their labor and who are deprived of political rights" (Rancière 1999, 37). The judge then allows "proletarian" to be added to the court's list of professions. Rancière (1999, 38-39), in his analysis of this event, argues that everything turns on the acceptance of a double word, "profession":

For the prosecutor, embodying police logic, profession means job, trade: the activity that puts a body in its place and function.... But within revolutionary politics, Blanqui gives the same word a different meaning: a profession is a profession of faith, a declaration of a membership of a collective.

This collective, Rancière continues, is not a social group but is part of a process of subjectification: "Proletarian" subjectification defines a subject of wrong, the counting

\footnotetext{
${ }^{35}$ Rancière $(1999,40)$ himself does not think this necessarily poses a problem.
} 
of the uncounted. This clearly is an example of a process establishing a relation between two worlds.

Yet it is not clear that subjectification here involves disidentification. Blanqui rearticulates what it means to be a proletarian and a member of a profession and the judge's response here is not dissimilar to that of the patricians who come to hear the words of the plebs as logos rather than phônê. This does not, however, rest upon a process of disidentification. Moreover, it is also clear that for the term proletariat to become a term that opens up new worlds, much else has to occur. Although this is in part a matter of the specific history and destiny of the term proletariat, the more general question here concerns the import of the inscription of an egalitarian logic. Rancière $(1999,40)$ acknowledges that such inscriptions might be fragile and fleeting. However, his acknowledgment could be read in two different ways. One could argue, as Rancière repeatedly does, that what matters is the specific miscount. As he puts it (2011,9): "All my historical research has been aimed at ... showing that the history of social emancipation had always been made out of small narratives, particular speech acts, etc." Even so, Rancière does seek to offer an account of democracy and egalitarian inscription that exceeds the local and the specific miscount, and that provides tools to think critically about democracy beyond the confines of the local and the present. Here lies its strength.

However, if the verification of equality is to take the form of an inscription that resignifies the sensible, then it has to have the power to reconfigure. This means that it has to be potentially more than fleeting if reinscription is to have any significance at all. In this light, it is clear that disidentification is not sufficient to the task. We have seen that although it does play a crucial role in opening up new worlds, the very figuring of such new worlds, of alternative possibilities, requires more. The opening up of new worlds presupposes a characterization of subjectification that focuses not only on disidentification, but also on the possibility of reidentifying with an alternative vision. In contrast to his theoretical writings, Rancière is remarkably clear on this in his earlier historical studies. For instance, in The Nights of Labor, significantly subtitled The Workers' Dream in Nineteenth-century France, he argues (1989, 20) that

It is the secret of others that the worker needs to define the meaning of his own life and struggle. Not the "secret of the commodity"... It is not knowledge of exploitation that the worker needs in order "to stand tall in the face of that which is ready to devour him." What he lacks and needs is a knowledge of self that reveals to him a being dedicated to something else besides exploitation, a revelation that comes circuitously by way of the secret of others: that is, those intellectuals and bourgeois people with whom they will later say, and we in turn will repeat, they want to have nothing to do-and especially not with any distinction between the good ones and the bad ones.

Rancière continues his analysis, suggesting that the world of the bourgeoisie divides into two: "those who live a vegetative existence, the rich people so persis- tently depicted as stretched out indolently on their sofas or feather beds" and those, by contrast, "who desert the domestic cult of Baal to set out in search of the unknown: the inventors, the poets, the lovers of the people and the Republic, the organizers of the cities of the future, and the apostles of new religions" $(1989,20)$. The worker, he argues, needs all these people, "not to gain scientific or scholarly knowledge of his condition, but to entertain and maintain his passions and desires for another world" (1989, 20, emphasis added). Hence, the possibility of entertaining and maintaining passions and desires for another world arises not simply from disidentification, but from "revelation of a different world and the initiation of a new kind of relationship between beings," from other possibilities becoming visible $(1989,116)$.

In terms of the initiation of new relationships between political subjects, Rancière argues repeatedly that a democratic community must be both a community of "interruptions" and one in which "intervals constructed between identities, between spaces and places" inaugurate a political "being-together" as "a being-between: between identities, between worlds" $(1989,137) .{ }^{36}$ However, there is a gap between discourses of disidentification, which often take the form of discourses of purity, and the institution and maintenance of complex new forms of identification capable of sustaining an ethos of egalitarian inscription. Addressing this gap between disidentification and the possibility of reidentification with another way of doing things necessitates a reworking of Rancière's use of the category of identification. I have already noted his association of identification with the extant order, the natural places and hierarchies offered by the police. If, however, this conflation of a theoretical category with a particular politics is questioned, it becomes possible to provide a much more nuanced explication of processes both of disidentification (turning away from) and of reidentification (turning toward), neither of which can be presumed to take a specific, predetermined political form. ${ }^{37}$ That is, nothing, in itself, follows from identification as such. All depends on the precise forms of identification and the possibilities opened up or closed down by particular identifications. Significantly it also allows one to address a persistent criticism of Rancière's work, namely the presumed homogeneity of the police order. If attention is directed, as Rancière himself argues, to the specificity and singularity of specific forms of identification, it becomes much more problematic to assume that there is one wholly hegemonic form of identification that dominates the police order and from which there is no escape. This issue is

\footnotetext{
36 "The democratic process is the process of perpetually bringing into play, of invention of forms of subjectivation, and of cases of verification that counteract the perpetual privatization of public life. Democracy really means, in this sense, the impurity of politics" (Rancière 2006, 62).

${ }^{37}$ Conceptually I would argue that "disidentification" remains a form of identification, albeit one with a negative basis. In this case, it makes sense to deploy the broader category of identification as involving both an aspect of distancing oneself from another and of drawing on alternatives to produce novel subject positions.
} 
absolutely central, because without it no reconfiguration of the sensible is possible. To put it in different terms: a reconfiguration of the sensible requires, of necessity, the possibility of altering and initiating new relations between beings, and that cannot occur so long as one holds onto the idea of an undifferentiated police order. Let us now turn to an examination of the question of ethos, which addresses, precisely, the relational dispositions between people.

\section{THE ROLE OF EXEMPLARS IN EGALITARIAN INSCRIPTION}

I take the characterization of the plebian revolt by Ballanche to foreground the world disclosive character of staging equality. As Rancière himself puts it, "politics is both argument and opening up the world where argument can be received and have an impact" (1999, 56), bringing about a different way of seeing things:

Political invention operates in acts that are at once argumentative and poetic, shows of strength that open again and again, as often as necessary, worlds in which such acts of community are acts of community. That is why the "poetic" is not opposed here to argument. $(1999,59)$

Hence, the question is how he conceives of this impact? What must be shifted in order for a dispute to reconfigure the regime of the sensible? I wish to focus on one particular candidate, namely the possibility that such an impact may be felt or conceived through a shift in ethos. That is, the writing of names in the sky, if they are to have an impact, will have to have a wider effect, a reconfiguring effect, and this can be thought through the instatement of a different ethos.

However, Rancière consistently objects to a range of possible candidates for this task, arguing that they all fall prey to the order of the police. He objects to the idea that democracy has anything at all to do with a way of being. ${ }^{38}$ Ethos, he argues, signifies an abode, a place or location and ethics; it means that one interprets a sphere of experience as the exercise of a property or a faculty possessed in common by all those who belong to a location. But this precisely is where Rancière locates the problem, because the purported commonality of properties such as logos is always already divided. ${ }^{39}$ Hence, he argues that politics as a set of practices should not be regulated by "ethics conceived as the instance pronouncing values or principles of action in general" $(2011,4)$. In contrast, the egalitarian inscription is conceived of as a break with an ethos, as a distancing from it.

\footnotetext{
38 "It is not their ethos, their 'way of being,' that disposes individuals to democracy but a break with this ethos, the gap experienced between the capability of speaking and any 'ethical' harmony of doing, being, and saying" $(1999,101)$.

39 As he puts it $(2009 \mathrm{~b}, 4)$ : "As is well known, it soon is made apparent that this common property is not shared by everyone; there are human beings who are not entirely human beings. For instance, Aristotle says, the slaves have the aisthesis of language (the passive capacity of understanding words), but they don't have the hexis of language (the active power of stating and discussing what is just or unjust)."
}

Is there a way to conceive of egalitarian inscription that would do the work of disruption and distancing that Rancière has in mind, but that would also, further, be capable of inscribing such distancing into a way of being, an ethos, yet in a manner that would not by definition fall prey to the order of the police? From the foregoing it is clear that the work of such an inscription should be conceived along a series of strictly specified lines. First, it should conceive of political subjectivity in a manner that avoids a given and pure conception of identity in favor of a critical subjectification. Second, it should facilitate the possibility of opening up new worlds. This means that it should be futural in character (Rancière 1999, 50): It should allow political actors to "write names in the sky"-to imagine unthoughtof possibilities. Third, it should conceive of political community, not in substantive terms, but in terms that are attentive to the inevitable closures necessarily accompanying any police order. Taken together, these specifications resonate strongly with a certain contemporary understanding of a democratic ethos, developed in the work of Cavell, conceived of as an aversive ethos, an ethos that is precisely not that of a location or a place, but of an aversion to it. In what follows, I turn to a discussion of the features of such an ethos, arguing that it is capable of providing us with the means to think through crucial aspects of "writing a name in the sky" that remain underemphasized in Rancière's writings. I will focus in particular on the role of the exemplar in constituting a horizon of possibilities, one that adumbrates a conception of democratic subjectivity that foregrounds (critical) responsiveness, thus highlighting the placing of demands on the moral order (or the police order, to put it in Rancière's terms).

To amplify this point, let us return again to the work done by Rancière's examples: Auguste Blanqui, the revolt of the plebs on the Aventine Hill, the disidentification from a certain "French subject" that occurred in the wake of the Algerian war. Most commentators on Rancière's work focus on the disruptive character of each of these examples. However, as we have seen, they have a further role that exceeds that of disruption. Each also acts as an exemplar of the possibility of being and acting differently. Like the figure of Nora, they embody claims exceeding existing moral discourse, they "put the social order as such on notice" (Cavell 1990, 109), as well as manifesting for us another way of doing things. The protesters in Tahrir Square not only demanded an extension and deepening of the right to be heard, but also organized themselves in a manner that enacted alternative forms of social arrangement. The much commented-upon organization of teams to provide childcare and to clean the square signifies attentiveness to the position of women and the need for social care. ${ }^{40}$ This is the work of egalitarian inscription: Opening up a horizon of imagination in which other ways of conceiving political community are kept alive

\footnotetext{
${ }^{40}$ See, for instance, the reportage in the New York Post, February 12, 2011: "Protesters clean up Tahrir Square, as army pledges civilian rule."
} 
and, importantly, can be (re)inscribed repeatedly. ${ }^{41}$ On this reading, reinscription always takes into consideration the precise, local conditions, yet simultaneously acts as a call to open ourselves up to other, foreign possibilities manifested in the declaration of a dispute with the extant order. It is Rancière's attention to the singular character of these examples that leads commentators to overemphasize the ruptural quality of democracy in his writings, and thus to miss the wider significance and power of his historical cases. However, as Rancière suggests, his work may be thought of as "panecastic philosophy" because it deploys "a method for finding in every (ekaston) peculiar manifestation" the "whole (pan) of its power" (2009a, 281). Hence, his "little narratives" that are extracted from the fabric of social history, where they are "expressions of a certain 'workers'culture," may become, instead, "statements on and shifts in the distribution of the sensible" (2009a, 281). The words resound. In doing so, they are concrete enunciations. But they also contain a principle of untimeliness and universalization: "You must also draw the line of escape, the line of universalization" (Rancière 2009a, 282).

Despite this very clear emphasis on the exemplariness of his examples, Rancière refrains from drawing out a generalizable ethos of engagement. The reason for this, as I have argued, arises in part from the specific understanding of ethos as located, signifying a place, and in part from his conceptualization of subjectivity as disidentification. Paradoxically, then, he refrains from thinking through what is required on the side of the extant order, for the exemplar to do its work of inscription. In each of these respects Cavell's work could usefully supplement Rancière's writings.

An emphasis on (re)inscription through the work of the exemplar allows one to retain the importance of singularity and historicity, while not remaining trapped in what is merely fleeting, sporadic, fugitive, and interruptive. ${ }^{42}$ Thinking about the exemplarity of the example, enables one to focus on both the distancing from the given order, a turning away, and the possibility of another way of being and acting-a turning towardthat is inscribed in it. This both-and logic helps to counter the force of much of contemporary democratic theory, which seeks to resolve dilemmas regarding rupture and institution through an exclusive emphasis on one or the other. ${ }^{43}$ In contrast, Cavell's Nietzschean rendering of exemplarity captures the double logic that

\footnotetext{
41 This rendering of inscription relies on insights from Derrida's treatment of the possibilities of "grafting" and iteration (Derrida 1988), which emphasizes the complex interaction between change and repetition, such that every repetition or reinscription contains both an element of newness, of break with an extant context, and an element of continuity, which allows it to make sense, to be intelligible. 42 Melissa Lane (2011) provides a general discussion of the work of historical exemplars in political theorizing. An excellent range of contributions dealing with historical forms of exemplarity are also contained in Gelley (1995).

${ }^{43}$ Here I draw on Derrida, who refuses what he regards as the "blackmail" of either-or arguments, and explores the possibility of thinking one possibility together with another. As already noted, either-or forms of argumentation-either complete break or conservative continuity-occur across the spectrum of democratic theory.
}

is required here. On one hand, it allows for a certain disidentification (Rancière) or aversion (Cavell) to the given, a critique of conformism that also resonates with Arendt's. ${ }^{44}$ On the other, it keeps open the possibility of an identification with that which exceeds the current order through a focus on the demands these exemplars place upon us; upon everyone, and also upon those who occupy the positions of "the police."

Inherent in Cavell's vision of democracy is the goal of demonstrating to others the partiality of society's arrangements, by offering oneself and one's position as presenting an alternative self for those others (Hammer 2002, 132-33). An important part of this work of both making available and keeping open the possibility of another way of doing things is done by such exemplars. ${ }^{45}$ As Conant (2001, 193, emphasis added) puts it, "To be an exemplar ... is to be someone whose way of life ... places a demand on others to emulate his example in a non-imitative fashion." Hence, an exemplar provides a concrete representation of something one aspires to (Conant 2001, 195). Its role is to unsettle us-provoking disidentification, in Rancière's terms-and to open up horizons of imagination not previously available to us. What needs to be shown is how this rendering of exemplarity could contribute to our understanding of the development and fostering of alternative forms of identification and inscription.

Let us now return to Cavell's exemplars in this context. Nora acts as an exemplar in that she manifests another way of being, opening up potential new horizons that do not leave things unchanged: Her departure demands a response at the same time as it stimulates thinking of imaginative ways to "light out from the common ways" (Walker, 2001, 175). Cavell $(1990,111)$ argues that Nora's taking off her "fancy clothes" upon leaving Torvald at the end of the play is an enactment of inner change. He also argues that how Torvald picks up the pieces "is as morally fateful for him as Nora's leaving is for her" (Cavell, 1990, 113). Torvald can, Cavell notes, persist in his initial view of Nora. That, precisely, is what disturbs Cavell about the idea that we should act to ensure that our conduct is "above reproach," suggesting as it does a rejection of perfectionism (1990, 113). Cavell and Rancière both acknowledge that there

However, they also take other forms. Notable examples include what Foucault called "Enlightenment blackmail"-the idea that one has to be either for or against Enlightenment-and the dichotomous division between power and domination-free communication in Habermas. These older debates continue to have an impact on how we think of democracy and of possibilities that are more complex than what the either-or form allows.

44 Cavell's Emersonian emphasis on aversion clearly resonates with Arendt's critique of conformism. Arendt $(1994,744)$ depicts it thus: "Morality collapsed into a mere set of mores-manners, customs, conventions to be changed at will-not with the criminals, but with ordinary people, who, as long as moral standards were socially accepted, never dreamt of doubting what they had been taught to believe in."

${ }^{45}$ Ferrara (2006, 66-67) argues, for instance, that "Alongside the 'force of things'-of what exists, of habits and traditions-and the 'force of ideas'-of what should or ought to be the case-stands the force of the example, which replaces the normativity of a law or principle with the normativity of the example." 
are no guarantees here. That is why the political work of the exemplar is so important.

To break out from the common way presupposes not only a sense of dislocation, of dispute and of dissatisfaction, but also the availability of an alternative imaginary horizon, something transcending the here and now, disclosing at least the possibility of new worlds. It is here that Rancière's historical exemplars come into play and take on their full force. Exemplars "manifest another way," are always singular, yet in their singularity they facilitate the glimpsing of a universal, of another way of doing things. For Cavell $(1990,59)$, friendship and authorship are paradigm cases of exemplars, allowing us to strive for the next self. He suggests, for instance, that Plato's Republic is an obvious candidate to illustrate this work of conversation between friends. The friend, who is also an enemy "contesting my present attainments" $(1990,59)$, is

intellectually authoritative because ... his life is somehow exemplary or representative of a life the other(s) are attracted to ... the self finds that it can turn (convert, revolutionize itself) and ... a process of education is undertaken . . . in which each self is drawn on a journey of assent to ... a further state of that self, where ... the higher is determined not by natural talent but by seeking to know what you are made of and cultivating the things you are meant to do; it is a transformation of the self which finds expression in ... the imagination of a transformation of society. (Cavell 1990, 6-7)

Every one of us has the inherent capacities needed for this process-there is nothing elitist about this argument. The cultivation of these capacities takes place, among other things, through the work of exemplars that are constituted, not given. The "commonalities" they propose, as Zerilli $(1998,11)$ puts it, "must be articulated through the interplay of diverse political struggles-rather than discovered and then merely followed, as one follows a rule." Thus, exemplars are products of political struggle: The fact that Nora and Tahrir square are recognizable to us as exemplars of struggles against inequality is the result of ongoing political struggles that have contributed to the sedimentation and inscription of a certain democratic, egalitarian ethos. $^{46}$

\section{TOWARD AN ETHOS APPROPRIATE TO EGALITARIAN INSCRIPTION}

Nevertheless, the work of exemplarity done by Tahrir Square and Nora is not the same. Perhaps one of the pivotal contrasts between Ranciere's and Cavell's exemplars concerns their respective renderings of subjectivity. Although Rancière's is limited by his emphasis on disidentification, it has the advantage of explicitly dealing with collective forms of identification. In contrast, Cavell's focus on the individual is often taken to

\footnotetext{
46 "Sedimentation," a geological metaphor, is drawn from Derrida's reading of Husserlian phenomenology. It suggests the process through which the meaning of a term becomes fixed and its origins forgotten as a result of a process of layering that occurs over time.
}

suggest that his writings are somehow nonpolitical, and commentators are skeptical as to its potential political import. Shulman (2011), for instance, argues that a focus on the collective is necessary if we are to develop a properly political understanding of ethos in general and an ethos of responsiveness more specifically. $\mathrm{He}$ suggests that a "political form of acknowledgment ... requires a compelling counter-narrative that connects private troubles to public causes," and he doubts that Cavell provides this. Others have similarly emphasized the fragility of the first person plural in Cavell. Hammer $(2006,165)$ notes that " $\mathrm{t}] \mathrm{he}$ 'we' in Cavell is a contested, fragile space of individual human voices that are exercised without any communal or metaphysical assurances." Despite skepticism in this regard, there is little doubt that Cavell's focus on conversation, on "speaking together, about matters of common importance," is deeply political (Cavell 2006, 265). The emphasis in his writings on politics as claim-making foregrounds the task of citizenship as one of making and staking claims; of working out, together, through these processes, what we are responsible for, with whom we are in community (Cavell 1982, 23). Norris $(2006,33)$ puts it succinctly: "I don't have, so to speak, a choice between myself and others, the individual and the community. ... The community both gives me a political voice, and can take that voice back from me." Indeed, Cavell's elaboration of exemplarity addresses these issues through its focus on the processes involved in the constitution of claims of the common, what we may call "ours" (Zerilli 2005, 170).

The view of exemplarity is sustained by a conception of subjectivity that starts from the riven character of every identity and moral order. Rather than focusing exclusively on the division of the sensible between the extant order and those excluded, "the part of those who have no part," division is thought of as running through the self and through society, between a given, attained self or state of society, and a next or future state of self and society. ${ }^{47}$ Despite the focus on the self, it is clear that Cavell breaks decisively with a liberal understanding of the individual as an isolated self, fully constituted before he or she enters into any relation with others. The self, for him, is inherently divided and doubled; any autonomy is always something to be attained, and if attained, always remains threatened and precarious (Mulhall 1994, 292-310). Moreover, it is important that the identity of the self-both attained and next (futural)-requires "the recognition of an otherthe acknowledgment of a relationship." ${ }^{48}$ The emphasis

\footnotetext{
${ }^{47}$ Cavell $(1990,59)$ notes in this respect that for Emerson "we are divided not alone between the intellect and sense, for we can say that each of these halves is itself split. We are halved not only horizontally but vertically-as that other myth of the original dividing of the human pictures it-as in Plato's Symposium, the form of it picked up in Freud, each of us seeking that of which we were originally half, with which we were partial."

48 Cavell $(1990,31)$ argues that the working out of any identity can only occur in the context of my relations to others: "Emerson's turn is to make my partiality the sign and incentive of my siding with the next or further self, which means siding against my attained perfection (or conformity), sidings which require the recognition of an other-the acknowledgement of a relationship-in which this sign is manifest."
} 
on relationality, which is necessary to any account of inscription, is constitutive of the human for Cavell. He suggests that

Whatever Moral Perfectionism knows as the human individual, one who is not everything but is open to the further self, in oneself and in others, which means holding oneself in knowledge of the need for change; which means, being one who lives in promise... which in turn means expecting oneself to be, making oneself intelligible as an inhabitant now also of a further realm-Kant and Mill, and Nora Helmer and Tracy Lord in The Philadelphia Story, call this the realm of the human-and to show oneself prepared to recognize others as belonging there ... This is not a particular moral demand, but the condition of democratic morality. (Cavell 1990, 125, emphasis added)

Relationality as constitutive of a democratic ethos avoids the overly individualistic emphasis of which Cavell is often accused and places the self always already in relation to others, as well in relation to his or her society and the demands it places upon him or her. Bates $(2003,42)$ argues this point thus:

Hence one must be careful in interpreting the phrase from Emerson's "History" that Cavell quotes-the "unattained but attainable self." This is not a designation of some specific state to be reached ... What perfectionism wants is the possibility of self-transformation according to an ideal that is internal to the self's constitution rather than one that comes from without. However, we need to remember that what is "internal" and what comes from "without" are themselves not fixed and permanent categories. If the transfiguration of any particular state of the self is to be possible, then even these categories will be capable of transformation. Of course, every part of every state of my self is how I relate to the society that has helped to form me.

The nonteleological character of the perfectionism advocated by Cavell (1990, xxxiv) leaves no role for the idea of a true, or indeed a false self. Hence, the transfiguration of the self always occurs in response and in relation to the extant order and it is here that exemplars play a crucial role.

As we have seen, there are two aspects of this process that are important. The first relates to the process of distancing oneself from the given order. In Rancière, this work is done through a process of disidentification. In Cavell, drawing on Emerson and Nietzsche, it takes the form of a critique of conformism. Cavell $(1990,146)$ argues in this respect that there are two key aspects shared by his two focal examples of perfectionism, Emerson and Nietzsche: a hatred of moralism/conformity and a disdain for the present state of things "so complete as to require not merely reform, but a transformation of the self." Politically, conformism for him entails a forgetting of the need to define oneself: "The conformist, by failing to estrange himself from prevailing opinion (as well as from himself), lets the community speak for him, yet without interrogating its right to do so" (Hammer 2002, 132). Oppositional, critical thinking, in contrast, consists in the ability to withstand conformism and to develop the resources to respond to the inevitable failures of democracy. ${ }^{49}$ Here the visibility of alternatives is crucial.

The advantage of Cavell's emphasis on the critique of conformism and the making visible of alternatives, in contrast to Rancière's, is that he explicitly situates them in relation to the extant (moral) order, as criticism of democracy from within $(1990,56)$. Let us recall the case of Nora: Her presence and departure place a demand upon the moral order, thus thematizing the issue of responsiveness. As Sparti $(2000,91)$ suggests, "our responsibility to others lies in our responsiveness to them." Torvald clearly fails to respond to Nora; he cannot hear her demands. What are the demands that we cannot hear today? Those expressing a sense of injustice often find themselves in Nora's position: faced with a society that cannot even begin to comprehend the sense of wrong expressed. This is the case today with a plethora of struggles within societies that regard themselves as democratic, and as otherwise, "above reproach." Here one only needs to think of responses to demands for same-sex marital unions-branded as "madness" and as "grotesque"-that echo Torvald in his unwillingness to engage with Nora and with her struggle to give voice to her sense of exclusion..$^{50}$

Responsiveness plays a crucial role in Cavell and it is precisely what is absent-for structural reasons-from Rancière's depiction of egalitarian inscription. The too sharp division between politics and the police order closes off this possibility for Rancière, leading him to see the matter almost exclusively from the perspective of the part that has no part. If a democratic political community must indeed be conceived of as both a community of "interruptions" and one in which "intervals constructed between identities, between spaces and places" inaugurate a political "being-together" as "a being-between: between identities, between worlds" (Rancière 1999, 137), then the consequences of an egalitarian inscription, also for those who occupy positions within the extant order, must be contemplated. Events such as those portrayed in the concrete historical cases discussed by Rancière make us aware of the painful distance from "perfect justice" in the current order, as Cavell $(1990,107)$ puts it, and demand a response, an examination and possible revision of the dominant position, hence provoking engagement with the claims articulated and disputes declared. Lacking responsiveness and engagement would be a form of aspect-blindness, where one is "unable or unwilling

\footnotetext{
${ }^{49}$ Cavell $(1990,56)$ argues the point thus: "I understand the training and character and friendship that Emerson requires for democracy as preparation to withstand not its rigors, but its failures, character to keep the democratic hope alive in the face of disappointment with it." I take this to mean, amongst other things, that we need to respond to these failures without falling back into cynicism and a crucial part of this process of keeping democratic hope alive is precisely the very character of responsiveness, not turning away saying that we stand "above reproach," as Rawls suggests.

${ }^{50}$ As recently as 4 March 2012, the head of the Scottish Catholic Church, Cardinal O'Brien, in an article for The Sunday Telegraph, branded campaigns for same-sex marriage as "madness" and as "grotesque."
} 
to realize the significance of the other's expressions" (Hammer 2002, 73). ${ }^{51}$

These provocations are significant not only for what they bring about in specific situations, for those miscounted, but also for the horizons of imagination they open up and keep open. Cavell (1990, xxxvi) marks their significance by arguing that the "demand of one's human nature for expression demands the granting of this human demand to others" and conversely, "showing that at some stage the scoundrel, opting out of membership in the intelligible realm, must seek to deprive others of expression, or their voice in choosing principles, or say, ideas, of their lives." From here it becomes possible to think through the demands of a politics of responsiveness, conceived of as the ability and responsibility to respond to the inevitable failures of democracy. These themes clearly intersect with contemporary debates on the nature of a democratic ethos and in particular with the recent turn to questions of responsiveness and receptivity. Much of this work focuses on the need to intensify our receptivity (Kompridis 2006, 209) and develop practices that can foster agonistic respect and critical responsiveness that works on the self in its response to others (Coles 1996; Connolly 1995). As Connolly (1995, xvi) argues, a pluralist culture needs to cultivate such critical responsiveness, because "to become something new is to move the self-recognition and relational standards of judgment endorsed by other constituencies to whom you are connected . . . to be white, female, heterosexual . . . is to participate in a diverse set of collective identifications .. . To alter your recognition of difference, therefore, is to revise your own terms of self-recognition as well." Debates concerning the centrality of a critical ethos to democracy can be traced back to the writings of Foucault and Nietzsche on agonism and can be contrasted with thinkers who either downplay or deny the role of ethos in developing their respective understandings of democracy. ${ }^{52}$ More recent writings on deliberative democracy have, however, also sought to articulate a specific ethos commensurate with deliberation. In this respect Laden $(2001,194)$ suggests that deliberative democracy itself must institute an ethos that is suited to the values of deliberation. Coming close to a Cavellinspired position that attention needs to be given to the practices through which we come to hold particular dispositions, most of these authors agree that a critical, responsive ethos is an indispensible part of democratic practice.

However, positions clearly still diverge on the role of struggle in such an ethos. Rancière foregrounds strug-

\footnotetext{
51 Cavell comments in this respect upon the case of slave owners, suggesting that although they see slaves as "a certain kind of human being" the slave owner denies his internal relation to these people. Hammer $(2002,74-75)$ summarizes what is at stake here in the following terms: this and other examples demonstrate "the extent to which we experience something as human depends not on its physical or mental features, but on our relation to it-the quality of our reciprocal stance."

52 Bernstein $(1998,291)$ argues in this respect that Habermas' discourse theory of law and politics presupposes but does not provide an explication of a democratic ethos.
}

gle and confrontation, whereas Cavell's writings often emphasize the conversational. Nevertheless, although the conversational emphasis in Cavell does not occur at the expense of other practices of "manifesting for another," 53 the manner in which he conceives of these practices could be supplemented with a more explicit consideration of confrontation and struggle. In a commentary on "Homer's Contest," Owen $(2002,125)$ argues that what is at stake here is a practical form that the instantiation of this attitude or ethos may take. He suggests that the agon captures this well, being a political culture in which "citizens strive to develop their capacities for self-rule in competition with one another, a culture that honors exemplary democratic citizens as setting standards that we should seek to match and surpass." To work in this fashion, an exemplar should be an excellence that is "attainable," because its educative function depends on its unsettling us, not on our following it in a slavish fashion (Cavell 1990, 6-7). It is notable that this Nietzschean rendering of exemplarity echoes John Stuart Mill's treatment of "originality," which he suggests opens our eyes, "which once fully done" allows one to be original oneself (Conant 2001, 229). These conditions are important because they make it clear that the educative role of the exemplar can only be fulfilled if someone or something is both related, similar to us (exemplarity is a mark of this), and different from us (exemplariness is an indicator of inessential difference). Establishing these similarities and differences, Rancière teaches us, comes about as a result of imaginative engagement in political struggle, a possibility, as Conant and Cavell point out, that is open to everyone.

Such standard setting involves attending to the "rough ground of politics," including the struggles in and through which exemplary qualities are developed (Honig 2011, 203). Emerson makes this all too clear. The responsiveness required of us is often jarring in character. We need to "affront and reprimand the smooth mediocrity and the squalid contentment of the times" (Emerson [1841] 1977, 147). That includes, for Cavell, confronting and responding to the inevitable failures of democracy. With this insistence on the ever-present possibility of the nonresponsiveness of the extant order, he addresses one of Rancière's key concerns, and goes beyond many theorists of the democratic ethos. ${ }^{54}$ These possibilities are precisely the wellsprings of Cavell's construal. Although he shares with Rancière the deep sense that our democracies often disappoint us, he focuses on the cultivation of an aversive ethos that seeks to prepare us for those failures.

\footnotetext{
53 For a discussion of the role of "manifesting for another" in Cavell's writing, see Norval (2011).

54 Cavell's work allows one to elaborate a conception of a democratic ethos that goes beyond a focus on the role of critique, and a supplement to relations of antagonism. Its nonteleological perfectionism facilitates a specification of the grammar of relations between citizensubjects that places demands and expectations upon participants in the democratic game.
} 


\section{"THERE IS NOTHING LEFT TO DO BUT TALK TO THEM"}

By way of conclusion, let us return to the scenarios with which we started, making visible the value of an account of inscription that explicitly foregrounds an aversive ethos. As I have suggested with the Aventine example, Rancière implicitly highlights what many of his readers focusing exclusively on his more explicitly theoretical later writings miss, namely, the possibility of inscription accompanying the declaration of a wrong. Such inscription involves a range of activities and practices, including the naming of hitherto unnamed subjects; the reclaiming of a given name; the staging of a wrong that seeks to reconfigure the sensible, thus reframing our existing ways of looking at a situation; the imagination of other possibilities; and seeing the universal in the singular. At the core of Rancière's writings, as in Cavell's, we find "a multitude of individuals such as Louis Gauny, Joseph Jacotot, Jeanne Derion" who "by their declarations, their grievances, and their acts transform the distribution of the sensible" (Rockhill and Watts 2009, 4). In reciting these names, Rancière engages in a double gesture, contesting histories written in the names of great men, as well as histories of the longue durée that "erase the possibility of acknowledging the actions of anyone whatever" (Rockhill and Watts 2009, 4). ${ }^{55}$ It is an abiding theme of Cavell's writings that they similarly draw on the works of figures whose status as philosophers are contested. Cavell $(1995,12)$ argues, for instance, that it is an important part of his project to reappropriate Emerson as a philosophical writer, because from this he could "learn something not only about Emerson, and not only about American culture, but something about philosophy, about what makes it painful." For both of these thinkers, then, invoking such names plays an important, critical role. For Rancière, as we have seen, it is important that these are not names of great men, but of figures hitherto unknown; singular, yet capturing something of the significance of a moment of political challenge and change. In Cavell $(1990,58)$, the theme of representativeness is also present and is equally linked to presenting "standards," yet in such a way as to emphasize our split nature, between our existing world and self and what we could become, our nextness. Blanqui's remarkable claim to the "profession" of proletarian, Jeanne Deroin's equally striking presentation of herself as a candidate for an election in which women cannot run: Both stage nonexistent rights, constructing a singular, polemical universality (Rancière 1999, 42). As Bosteels $(2009,163)$ puts it, "the universal exists only in the singular-that is, in the plurality of particular modes, places, and operations."

Yet, despite the presence and explicit acknowledgment of exemplarity in Rancière's work,${ }^{56}$ his analysis

\footnotetext{
55 Rockhill and Watts $(2009,4)$ note that in doing so Rancière distances his work explicitly from the Annales school.

56 Rancière (1999, 41) calls Jeanne Deroin's actions "exemplary." For a more extended historical treatment of Deroin, see Scott (1996, chap. 3).
}

of Roman patricians' acceptance of the plebeians' "becoming beings who may very well make promises and draw up contracts" is brief $(1999,25)$. He notes that from "the moment the plebs could understand Menenius's apologia ... they were already, just as necessarily, equals." The Roman Senate concludes that "since the plebs have become creatures of speech, there is nothing left to do but to talk to them" (Rancière, 1999, 25-26)..$^{57}$ This brief gesture, I have argued, covers over precisely the question of responsiveness and the need, for the plebeian speech act to become effective, for it to be inscribed in the extant order. The responsiveness in question here is not predetermined. Yet this does not make it any less significant. The patricians accepted the staging of equality by the plebeians; elsewhere, the staging of equality is less successful. The story of the Scythian slaves is a case in point; they fail to turn their wargenerated equality into political freedom (Rancière 1999, 13). What this contrast foregrounds is that the gains of struggle need to be defended, beyond their initial staging. This is necessary, not only in cases of the instituting moment of democracy, but also in wellestablished democratic orders, where we cannot risk thinking ourselves to be "above reproach." Part of this defense consists in cultivating an ethos of aversive responsiveness. Such an ethos, far from affirming a "way of being," alerts us to the necessity to challenge the "squalid contentment" of our age (Emerson 1977, 147) on an ongoing basis. It captures the intertwining of politics and the police order, and shifts the emphasis to a study of the places where they are inscribed in one another, allowing us to focus on the specific historical modalities in which this inscription occurs (Bosteels 2009, 170). This includes, crucially, an emphasis not only on the perspective of the articulators of a wrong, but on their addressees, those occupying privileged positions within the extant order. It requires attention to historical specificity and singularity, just as it calls for an emphasis on the politics of claim-making and the fragile collectivities it brings into being.

I started this reading with the suggestion that Rancière's view of democracy is torn on the horns of a dilemma: between democracy as a staging of equality that interrupts the extant order, and democracy conceived of as an inscription of equality that has the capacity to relocate and reshape it. As we know from much democratic theory, there are advantages to both of these characterizations. In Rancière, as in other theorists, they lead to radically divergent conceptions of democratic practice, each of which is accompanied by an emphasis on different aspects of political community. In the case of the former, the emphasis is on the division between the community and the part of the community that has no part. It makes visible the necessary exclusions accompanying any instituted order. In the latter the focus is on the imbrication and redoubling of names and it is suggestive of the possibilities of not only staging the miscount, but envisioning alternative

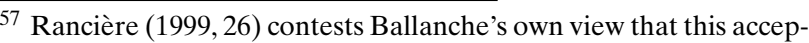
tance is matter of a "progressive revelation that can be recognized by its own signs," a "determined philosophy," but leaves it at that.
} 
ways of doing things. The latter is more evident where Rancière discusses his historical examples. As I have suggested, this should give us cause to reflect further on the role and function of such examples. Rancière turned to a detailed examination of the working class intellectual production that thrived in France in the 1830 s and 1840 s in the wake of his break with $\mathrm{Al}-$ thusser, turning Althusser's privileging of scientific insight over popular delusion on its head. As Hallward $(2006,109)$ points out, Rancière's writings consistently explore the presumption that everyone shares equal power of speech and thought. Yet, as I have suggested, these historical cases as they appear in his later theoretical writings stop short of working through the consequences of a staging of equality for the relation between the order of the police and the part that has no part. The reasons for this are doubtless multiple and complex, but I have focused attention here on one specific aspect of that larger problem. In considering his conception of subjectivity and the difficult relation between subjectification and disidentification, I have suggested that the latter is still a form of identification, and that it is necessary to move beyond identification understood as a (negative) distancing to address the mechanisms of the egalitarian inscription.

Egalitarian inscription, if it is to mean anything beyond the singular instance, needs to be enacted and conceptualized in a way that makes it possible not only to maintain the insights specific to it, but to extend their reach and impact to a wider domain. Conceptualizing egalitarian inscription in this way can be achieved by thinking more carefully about the role of the exemplar in the constitution of alternative political horizons. Rancière's own historical cases, I have suggested, could be conceived of as exemplars, which would then open up the analysis to consider the work of exemplars in relation to a wider audience-those occupying places in the extant order-and of their responses to the theatre of egalitarian inscription. Such an account is only possible once one problematizes the sharp division between the police order and the moment of politics. Thinking of egalitarian inscription as a moment of bringing the universal into play comes at the price of giving up that sharp division. However, this is not something that should be lamented, for the rethinking of the relation radically opens up the police order for contestation and politicization.

If, finally, one thinks of democracy not as a disruption occurring in rare instances and on the margins of society, but as an aversive practice that could occur anywhere and with consequences for how we think of political community everywhere, it is possible to foreground the central role of responsiveness to such practices. This is not an optional luxury that we can afford to add as an afterthought. It is, rather, a central aspect of democratic subjectivity and practice, without which, in Rancière's own terms, "writing a name in the sky" loses its ability to reconfigure the division of the sensible. This reconfiguration has the potential to dissolve the extra-ordinary/ordinary division, the dualism that holds much of democratic theory captive, for it provides us with the resources to enjoy the fruits of democratic vitality, yet without too quickly subordinating these energies to legal and institutional procedures. In addition, and this is perhaps its most crucial contribution, it emphasizes the positive, critical, and energizing role of moments of staging a wrong for the extant order. As so many of our contemporary struggles attest, moments of challenge and critique, of the staging of democratic demands, are not important only because they make us aware of and demand that we address existing wrongs. They also are crucial to the deepening and sustaining of a democratic ethos, an ethos that foregrounds democratic responsiveness. The "nextness" that for Cavell characterizes our subjectivity allows us to think of interruption and inscription as ongoing possibilities that place serious normative demands upon democratic orders.

\section{REFERENCES}

Ackerman, Bruce. 1991. We the People: Foundations. Cambridge, MA: Harvard University Press.

Arendt, Hannah. 1994. "Some Questions of Moral Philosophy." Social Research 61 (4): 739-64.

Bates, Stanley. 2003. "Stanley Cavell and Ethics." In Stanley Cavell, ed. Richard Eldridge. Cambridge: Cambridge University Press, $15-47$.

Bernstein, Richard. 1998. "The Retrieval of the Democratic Ethos." In Habermas on Law and Democracy: Critical Exchanges, eds. Michael Rosenfeld and Andrew Arato. Berkeley: University of California Press, 287-307.

Bohman, James. 1996. Public Deliberation: Pluralism, Complexity, and Democracy. Cambridge, MA: MIT Press.

Bosteels, Bruno. 2009. "Ranciere's Leftism, or, Politics and Its Discontents." In Jacques Rancière: History, Politics, Aesthetics, eds. Gabriel Rockhill and Philip Watts. Durham, NC: Duke University Press, 158-75.

Cavell, Stanley. 1982. The Claim of Reason: Wittgenstein, Skepticism, Morality, and Tragedy. Oxford: Oxford University Press.

Cavell, Stanley. 1990. Conditions Handsome and Unhandsome: The Constitution of Emersonian Perfectionism. Chicago: Chicago University Press.

Cavell, Stanley. 1995. Philosophical Passages: Wittgenstein, Emerson, Austin, Derrida. Oxford: Blackwell.

Cavell, Stanley. 2004. Cities of Words: Pedagogical Letters on a Register of the Moral Life. Cambridge, MA: Belknap Press of Harvard University Press.

Cavell, Stanley. 2006. "The Incessance and Absence of the Political." In The Claim to Community: Essays on Stanley Cavell and Political Philosophy, ed. Andrew Norris. Stanford, CA: Stanford University Press, 263-318.

Coles, Romand. 1996. "Liberty, Equality, Receptive Generosity: Neo-Nietzschean Reflections on the Ethics and Politics of Coalition." American Political Science Review 90 (2): 375-88.

Conant, James. 2001. "Nietzsche's Perfectionism: A Reading of Schopenhauer as Educator." In Nietzsche's Postmoralism: Essays on Nietzsche's Prelude to Philosophy's Future, ed. R. Schacht. Cambridge: Cambridge University Press, 181-257.

Connolly, William E. 1995. The Ethos of Pluralization. Vol. 1 of Borderlines. Minneapolis: University of Minnesota Press.

Dean, Jodi. 2005. "Zizek against Democracy." Law, Culture, and the Humanities 1 (2): 154-77.

Derrida, Jacques. 1988. Limited Inc. Evanston, IL: Northwestern University Press.

Dillon, Michael. 2003. "(De)void of Politics? A Response to Ranciere's Ten Theses on Politics." Theory and Event 6 (4). http:// muse.jhu.edu/journals/theory_and_event/v006/6.4dillon.html (accessed August 3, 2012).

Emerson, Ralph Waldo. [1841] 1977. "Self-reliance.” In The Portable Emerson, ed. Carl Bode, in collaboration with Malcolm Cowley. Harmondsworth, UK: Penguin Books. 
Ferrara, Alessandro. 2008. "Does Kant Share Sancho's Dream? Judgment and Sensus Communis." Philosophy and Social Criticism 34 (1/2): 65-81.

Foucault, Michel. 1988. Politics, Philosophy, Culture: Interviews and Other Writings 1977-1984. Ed. Lawrence D. Krizman. New York: Routledge.

Foucault, Michel. 2007. Security, Territory, Population: Lectures at the Collège de France 1977-1978. Basingstoke, UK: Palgrave Macmillan.

Frank, Jason. 2009. "Staging Dissensus: Frederick Douglas and 'We, the People."' In Law and Agonistic Politics, ed. Andrew Schaap. Farnham, UK: Ashgate, 87-104.

Frank, Jason. 2011. "Standing for Others: Reform and Representation in Emerson's Political Thought." In A Political Companion to Ralph Waldo Emerson, eds. Alan M. Levine and Daniel S. Malachuk. Lexington: University Press of Kentucky, 383-414.

Gelley, Alexander, ed. 1995. Unruly Examples: On the Rhetoric of Exemplarity. Stanford, CA: Stanford University Press.

Habermas, Jürgen. 1992. The Structural Transformation of the Public Sphere. Cambridge: Polity Press.

Hallward, Peter. 2006. "Staging Equality: On Rancière's Theatrocracy." New Left Review 37: 109-29.

Hammer, Espen. 2002. Stanley Cavell: Skepticism, Subjectivity, and the Ordinary. Cambridge: Polity.

Honig, Bonnie. 1993. Political Theory and the Displacement of Politics. Ithaca, NY: Cornell University Press.

Honig, Bonnie. 2009. Emergency Politics: Paradox, Law, Democracy. Princeton, NJ: Princeton University Press.

Honig, Bonnie, and Marc Stears. 2011. "The New Realism: From Modus Vivendi to Justice." In Political Philosophy versus History? Contextualism and Real Politics in Contemporary Political Thought, eds. Jonathan Floyd and Marc Stears, Cambridge: Cambridge University Press, 177-205.

Kalyvas, Andreas. 2008. Democracy and the Politics of the Extraordinary: Max Weber, Carl Schmitt, and Hannah Arendt. Cambridge: Cambridge University Press.

Kompridis, Nikolas. 2006. Critique and Disclosure: Critical Theory between Past and Future. Cambridge: MIT Press.

Laclau, Ernesto. 1990. New Reflections on the Revolution of Our Time. London: Verso.

Laclau, Ernesto. 2005. On Populist Reason. London: Verso.

Laclau, Ernesto, and Chantal Mouffe. 1985. Hegemony and Socialist Strategy. London: Verso.

Laden, Anthony. 2001. Reasonably Radical: Deliberative Liberalism and the Politics of Identity. Ithaca, NY: Cornell University Press.

Lane, Melissa. 2011. "Constraint, Freedom, and Exemplar: History and Theory without Teleology." In Political Philosophy versus History? Contextualism and Real Politics in Contemporary Political Thought, eds. Jonathan Floyd and Marc Stears. Cambridge: Cambridge University Press, 128-50.

Lefort, Claude. 1986. The Political Forms of Modern Society: Bureaucracy, Democracy, Totalitarianism. Cambridge: Polity Press.

Lefort, Claude. 1989. Democracy and Political Theory. Minneapolis: University of Minnesota Press.

Markell, Patchen. 2006. "The Rule of the People: Arendt, Archê, and Democracy." American Political Science Review 100 (1): 1-14

Mulhall, Stephen. 1994. Stanley Cavell: Philosophy's Recounting of the Ordinary. Oxford: Clarendon Press.

Norris, Andrew. 2006. "Introduction: Stanley Cavell and the Claim to Community." In The Claim to Community: Essays on Stanley Cavell and Political Philosophy, ed. Andrew Norris. Stanford, CA: Stanford University Press, 1-18.

Norval, Aletta J. 2007. Aversive Democracy: Inheritance and Originality in the Democratic Tradition. Cambridge: Cambridge University Press.

Norval, Aletta J. 2011. "Moral Perfectionism and Democratic Responsiveness." Ethics and Global Politics 4 (4): 207-29.

Owen, David. 2002. "Equality, Democracy, and Self-respect:
Reflections on Nietzsche's Agonal Perfectionism." Journal of Nietzsche Studies 24: 113-31.

Parmele, Mary Platt. 2006. A Short History of Rome. New York: Cosimo Classics.

Patterson, Annabel M. 1991. Fables of Power: Aesopian Writing and Political History. Durham, NC: Duke University Press.

Rancière, Jacques. 1989. The Nights of Labor: The Workers' Dream in Nineteenth-century France. Trans. by John Drury. Philadelphia: Temple University Press.

Rancière, Jacques. 1995. On the Shores of Politics.Trans. by Liz Heron. London: Verso.

Rancière, Jacques. 1999. Disagreement: Politics and Philosophy. Trans. by Julie Rose. Minneapolis: University of Minnesota Press. Rancière, Jacques. 2003. "Comment and Responses." Theory and Event 6 (4). http://muse.jhu.edu/journals/theory_and_event/ v006/6.4ranciere.html (accessed August 3, 2012).

Rancière, Jacques. 2006. Hatred of Democracy. Trans. by Steve Corcoran. London: Verso.

Rancière, Jacques. 2009a. "Afterword/The Method of Equality: An Answer to Some Questions.” In Jacques Rancière: History, Politics, Aesthetics, eds. Gabriel Rockhill and Philip Watts. Durham: Duke University Press, 273-88.

Rancière, Jacques. 2009b. "The Aesthetic Dimension: Aesthetics, Politics, Knowledge.” Critical Inquiry 36 (1): 1-19.

Rancière, Jacques. 2011. "The Thinking of Dissensus: Politics and Aesthetics." In Reading Rancière: Critical Dissensus, eds. Paul Bowman and Richard Stamp. London: Continuum Books, 1-17.

Rockhill, Gabriel, and Philip Watts. 2009. "Introduction: Jacques Rancière: Thinker of Dissensus." In Jacques Rancière: History, Politics, Aesthetics, eds. G. Rockhill and P. Watts. Durham, NC: Duke University Press, 1-12.

Ross, Alison. 2009. "The Aesthetic Fable: Cinema in Jacques Rancière's 'Aesthetic Politics,"' SubStance 38 (1): 128-50.

Schaap, Andrew. 2009. "The Absurd Proposition of Aboriginal Sovereignty." In Law and Agonistic Politics, ed. Andrew Schaap. Farnham, UK: Ashgate, 209-24.

Scott, Joan Wallach. 1996. Only Paradoxes to Offer: French Feminists and the Rights of Man. Cambridge, MA: Harvard University Press.

Shulman, George. 2011. "Acknowledgement and Disavowal as Idiom for Theorizing Politics." Theory and Event 14 (1). http:// muse.jhu.edu/journals/theory_and_event/v014/14.1.shulman.html (accessed August 3, 2012)

Sparti, Davide. 2000. "Responsiveness as Responsibility." Philosophy and Social Criticism 26: 81-107.

Spinosa, Charles, Fernando Flores, and Hubert L. Dreyfus. 1997. Disclosing New Worlds: Entrepreneurship, Democratic Action, and the Cultivation of Solidarity. Cambridge, MA: MIT Press.

Tully, James. 2008a. Public Philosophy in a New Key, Volume I. Cambridge: Cambridge University Press.

Tully, James. 2008b. Public Philosophy in a New Key, Volume II. Cambridge: Cambridge University Press.

Viroli, M. 1992. From Politics to Reason of State: The Acquisition and Transformation of the Language of Politics 1250-1600. Cambridge: Cambridge University Press.

Walker, Brian. 2001. "Thoreau on Democratic Cultivation," Political Theory 29: 155-89.

Wittgenstein, Ludwig. 1989. Lectures and Conversations on Aesthetics, Psychology and Religious Belief. Oxford: Basil Blackwell.

Wolin, Sheldon S. 2004. Politics and Vision: Continuity and Innovation in Western Political Thought. Princeton, NJ: Princeton University Press.

Zerilli, Linda M.G. 1998. “"This Universalism Which Is Not One': A Review of Ernesto Laclau's Emancipation(s)." Diacritics 28 (2): 3-20.

Zerilli, Linda M.G. 2005. Feminism and the Abyss of Freedom. Chicago: Chicago University Press.

Žižek, Slavoj. 2011. "Democracy Is the Enemy.” LRB Blog, October 28. http://www.lrb.co.uk/blog/2011/10/28/slavoj-zizek/democracyis-the-enemy/ (Accessed August 3, 2012). 